\title{
Halal Tourism Development in East Lombok Regency
}

\author{
Miko Rayendra \\ Master Program Student of Geography Education \\ Faculty of Social Science, Universitas Negeri Padang, INDONESIA \\ Email: mikorayendra1993@gmail.com
}

\begin{abstract}
The purpose of this study were (1) to determine the perception of tourists on the readiness of halal tourism in East Lombok (2) to analysis a halal tourism development in East Lombok regency with SWOT analysis. Research uses descriptive qualitative method. According Sugiyono (2012) descriptive research is research that seeks describe and interpret data with objective measurements of the phenomenon. In addition, qualitative approach is used because researchers put the theory as the main starting point on the curiosity of researchers to measure the level of preparedness in developing halal tourism in East Lombok. Research aims to describe the potential of halal tourism destinations in East Lombok regency, analysis readiness through perception travel destination travelers in developing halal East Lombok, and clicking the analysis to development of halal tourism. The collection of data, in-depth interviews tourists. results of this study, East Lombok is quite optimal launched halal tourism in its tourism product and still need some improvement ata $u$ strategy to attract tourists.
\end{abstract}

Keywords: Halal tourism, Perception of Tourists, Tourism Development Halal

\section{Introduction}

The concept of halal tourism is a process of integrating values into the whole aspects of tourism activities. The value of Islamic law as a shared trust and confidence that Muslims become baselines in developing tourism activities (Kurniawan Gilang). Halal tourism considers the basic values of Muslims in its presentation ranging from accommodation, restaurants, to tourism activities that always refers to the norms of tourism (Tourism Review). The concept of Islamic tourism is the actualization of the concept to Islam where the value of halal and haram become the main benchmark, it means all aspects of tourism activities can not be separated from halal certification that must be a reference for every actor of tourism (Chookaew et al). According to Kamarudin The concept of Sharia can also be interpreted as tourist activities based worship and propaganda when the Muslim traveler can travel and mengagungi result creation or Allah (contemplative nature) with fixed obligations obligatory prayers five times a day and all this is well facilitated and away everything forbidden by him. Tourism is one of the emerging industries in Bangladesh. It is an activity aimed at Islam that aims to achieve physical, social and spiritual goals. Physical goals lead to a healthy and stress-free life, which then allows Muslims to serve God better. Islam encourages the visit of Muslim brothers, as it helps strengthen the Muslim community. A spiritual purpose strengthens one's obedience to God through the beauty and gift of God's creation (Hashim et al.). Thus, Islamic teachings influence to increase tourism activity in Muslim countries. Bangladesh has a great opportunity to develop Islamic tourism for the sake of economic sustainability while fulfilling the religious spirit. Malaysia, Saudi Arabia, Iran, Turkey has managed to adopt Islam and travel to attract many tourists le bih effectively (Tamanna Syeda Nusrat Fahima \& Evana Dooty). According to Mohamed and Mohd Nazari Ismail Battour one of the effective ways to access the market is to make kosher food widely available at the originally considered high-end destination a priority for Muslim travelers. Next, a Muslim friendly hotel should be available at the destination or at least separated sections of the hotel where there is no alcoholic beverage, no pork, halal food 
is provided. Muslim-friendly service is regarded as a starting point that could be Used in a promotional tool to market the destination as Muslims.

Indonesia is currently recognized as the world's largest Muslim-majority country, with a Muslim population of 207.176.162 (BPS, 2010) it is fitting for the tourism sector to see this as a potent new niche by combining the concept of tourism and value -the value to Islamiya then Shariah tourism can be the answer to the condition. (Suherlan in the journal Kurniawan Gilang). Halal travel, the designated destination shall provide kosher food, providing easy access to places of worship, and also accommodation, and services according to standards of Shariah. The Ministry of Parisiwata launched a halal tour in Indonesia with the aim of making Indonesia a friendly destination for Muslim tourists. Not only tourist destinations, facilities that support it must be as per halal standards of MUI. Therefore, halal tourism needs to be done and driven to travel agencies in order to bring Muslim tourists to a friendly and appropriate shari'ah. Deputy Head of Tourism Development and Promotion Archipelago, Esthy Reko Astuty said, many reasons why Indonesia can be a mecca for the world's halal tourism. First, Indonesia has many world tourist attractions that are equipped with amenitas, such as international standard hotel. Second, accessibility, namely international and domestic airport, and soft infrastructure development effort in the form of human resources. Third, halal tourism product is an alternative tourism product, meaning every tourist can also take advantage of various facilities. Halal tourism products are not only for middle eastern tourists, but also for countries like China, Korea, and Japan which is also a potential market. Fourth, Indonesia is the largest kosher travel market which is reinforced by a team of halal tourism product development acceleration.

One of the province prepare and seriousness became a tourist destination halal West Nusa Tenggara (NTB), one of the areas in Nusa Tenggara Barat who have the potential halal tourism is the East Lombok district based on data from the Central Statistics Agency (BPS) in 2010, Lombok The East has a total population of 1.104.232 inhabitants of Islam with a population of 1,105,582, with this data can be proved that East Lombok is a region whose population is predominantly Islamic, of course with the majority of the population of Islam certainly the population will certainly implement the teachings of Islam, in terms of religion that supports the district of East Lombok to become a tourist destination kosher can be seen from the attractions, which factor of attraction is the reason for tourists to visit East Lombok, East Lombok natural wealth is so great that the natural resources were utilized in world tourism. With the majority of the population to Islam and has a very beautiful natural resources in case Lombok eastern deserve to be halal tourism destination in West Nusa Tenggara and Indonesia of course. It needs to be studied is the perception of tourists on the readiness of halal tourism in East Lombok and clicking analysts a halal tourism development in East Lombok district using SWOT analysis.

\section{Method}

This research uses descriptive qualitative method. According Sugiyono (2012) descriptive research is research that seeks to describe and interpret data with objective measurement against existing phenomena. In addition, the qualitative approach is used because the researchers put the theory as the main starting point on the curiosity of researchers to measure the level of readiness in developing halal tourism in East Lombok regency. This study aims to describe the potential of halal tourism destinations in East Lombok regency, analyze the readiness of each tourist destination through the perception of tourists in developing halal in East Lombok regency, and produce appropriate strategies to develop halal tourism. Data collection, in-depth interviews of tourists and to analyze the development of halal tourism in East Lombok district researchers using SWOT analysis, SWOT analysis is done by creating worksheets containing four-part cross-section consisting of strengths, weaknesses, opportunities and threats. 


\section{Results and Discussion}

West Nusa Tenggara became the first area at a time the only one in Indonesia that has the Regional Regulation on halal tourism. In no. 2 Year 2016 on halal tourism, it is written that the scope of Halal Tourism arrangement in this Regulation covers destination, marketing and promotion, industry, institutional, development, supervision and financing. Managers of halal tourism destinations should build public facilities to support the convenience of halal tourism activities, such as places and equipment of Muslim tourist worship, as well as sacred facilities that meet sharia standards. This is formulated by Parliament of NTB to strengthen branding of halal tourism which is now attached to the province. Halal tourism concept becomes the main choice in tourism promotion in Lombok one of them in East Lombok regency. Plus the famous area of Lombok with the area "Thousand Mosque" which became one of the tourist attraction for the region in Lombok.

East Lombok readiness became destinations halal tourism can be seen through some of the main indicators are: attractions, hotels and restaurants, travel agencies and guides . Of these four indicators can be concluded that the East Lombok has tremendous potential to be developed as a tourist destination kosher because it has a tourist attraction which is quite a good variety of nature-based (Pink Beach Jerowaru, Geopark Rinjani in the village Sembalun), culture-based, Potential appeal it has been supported by the availability of amenitas that moslem friendly like places of worship in each tourist attraction. Muslim tourists is not too difficult to find a place of worship (prayer) for Lombok famous Thousand Regions Mosque. But there is still much that needs to be addressed if applying the concept of halal tourism in eastern Lombok, including the means of tourism infrastructure that supports the concept of halal tourism is not clear. Aspects of community readiness and supporting facilities is still a constraint in the development of halal tourism in Lombok East.

Accessibility constraints are still encountered in natural tourist attractions. Especially when researchers visited Pink Beach Jerowaru are located in areas where the access road which is very unfavorable for the vehicle passed, the government must pay attention to it because it will affect the existing tourist attraction in the area. Accessibility in terms of information availability can be obtained through internet media provided by both local government and tourism business actors. Local governments provide a website that provides information about tourist attractions in East Lombok. In general, the availability of accommodation at most hotels and guesthouses East Lombok that already exist to apply the concept of halal both in terms of products, services, and management. in every room at most of the hotels are already providing the mat, Qibla direction, in the supporting akomoda kosher travel still requires a clear standardization and so socializing policies in the regulation. Constraints in the provision of accommodation ie quality and service is still not maximized. Except in the Pink Beach area, Jerowaru because of facilities that support the attractions there has not been found. In general, the restaurant and food and beverage services provider in East Lombok regency in the processing and presentation have applied the principles of halal. There is a need standards that serve as guidelines for the restaurant and food and beverage service provider in East Lombok. 


\begin{tabular}{|c|c|c|}
\hline & STRENGHTS (S) & WEAKNESSES (W) \\
\hline & $\begin{array}{l}\text { - East lombok regency has potential variety } \\
\text { to become one of the strategic halal } \\
\text { tourism destination because east lombok } \\
\text { regency has a beautiful natural tourist } \\
\text { attraction, as well as the typical culture of } \\
\text { east lombok, and the Islamic keynote } \\
\text { values are thick in the area }\end{array}$ & $\begin{array}{l}\text { - Most of tourism industry actors in East } \\
\text { Lombok have not included certified } \\
\text { halal label } \\
\text { - Not ready Human Resources in } \\
\text { developing halal tourism, especially in } \\
\text { the field of service in East Lombok } \\
\text { - Some tourist complaints during a visit } \\
\text { to the district of East Lombok one of } \\
\text { them while visiting Pink beach area in } \\
\text { jerowaru Due to the lack of faslitas } \\
\text { such as road conditions are not good, } \\
\text { support facilities that have not been } \\
\text { there such as bathrooms and mushalla }\end{array}$ \\
\hline OPPORTUNITIES (O) & STRATEGY (SO) & STRATEGY (WO) \\
\hline $\begin{array}{l}\text { - Indonesia is a country with } \\
\text { the largest Muslim population } \\
\text { in the world and many } \\
\text { objects of nature is very } \\
\text { beautiful which is as a tourist } \\
\text { attraction halal one of which } \\
\text { is located in the East Lombok } \\
\text { regency } \\
\text { - The potential of halal tourism } \\
\text { is to visit foreign tourists who } \\
\text { will generate great foreign } \\
\text { exchange for Indonesia }\end{array}$ & $\begin{array}{l}\text { - The need for the promotion of packing } \\
\text { tour packages halal more attractive to the } \\
\text { tourists in the country and abroad visit } \\
\text { East Lombok regency } \\
\text { - Development of halal-standard facilities } \\
\text { in the tourist objects of East Lombok } \\
\text { regency } \\
\text { - Create a Halal Tourism Brand of East } \\
\text { Lombok Regency }\end{array}$ & $\begin{array}{l}\text { - Giving donations from both central and } \\
\text { local government, for example by } \\
\text { facilitating the filing and free financing } \\
\text { halal certification for the organizers or } \\
\text { tourist areas kosher East Lombok } \\
\text { - Human Resources Development on } \\
\text { Halal Tourism Awareness Group, and } \\
\text { held seminar or discussion about Halal } \\
\text { tourism in East Lombok Regency }\end{array}$ \\
\hline TREATHS (T) & STRATEGY (ST) & STRATEGY (WT) \\
\hline $\begin{array}{l}\text { - The absence of clarity of the } \\
\text { concept of halal tourism in } \\
\text { applied in Indonesia } \\
\text { - The development of halal } \\
\text { tourism in Indonesia is still } \\
\text { less quickly with the Islamic } \\
\text { countries who have already } \\
\text { applied the concept of halal } \\
\text { tourism }\end{array}$ & $\begin{array}{l}\text { Audit and assess each destination, } \\
\text { product, restaurant certified halal in the } \\
\text { district of East Lombok } \\
\text { - Improving coordination and socialization } \\
\text { of halal tourism in East Lombok Regency } \\
\text { by involving the community and related } \\
\text { instasi } \\
\text { - Working closely with countries that first } \\
\text { implement halal tourism }\end{array}$ & $\begin{array}{l}\text { - Keeping the characteristic and uniqueness } \\
\text { of nature and culture in the district of } \\
\text { East Lombok } \\
\text { - Increased promotion of halal tourism } \\
\text { and the provision of information service } \\
\text { of halal tourist-based communication } \\
\text { technology that understands the needs } \\
\text { of tourists } \\
\text { - Encouraging the tourism business to } \\
\text { learn and master a foreign language are } \\
\text { like language support English, Arabic } \\
\text { and other foreign language support that } \\
\text { is used to hook the foreign tourists }\end{array}$ \\
\hline
\end{tabular}

\section{Conclusion}

Traveler perceptions of readiness East Lombok as halal travel, namely from the aspect of tourist attractions most respondents tend to be expressed in good condition., Respondents tend declared ready. The accommodation available in East Lombok as a whole has applied Islamic principles in its service. However, no hotel has officially certified halal. East Lombok Regency is ready as a halal tourism destination because it has started to hold events and halal tour packages unless the hotel has halal certification of East Lombok as a halal tourist destination, need some improvement especially in institutional aspect especially human resources readiness. So it can be concluded that East Lombok Regency is quite optimal in working on halal tourism. But still need commitment and consistency in working on halal tourism in East Lombok regency 


\section{References}

Central Bureau of Statistics (BPS). (2010). Population by Region and Religion Embraced in Indonesia.

Battour, Mohamed \& Mohd Nazari Ismail. (2015) .Halal tourism: Concepts, Practices, challenges and future. Journal of Tourism Management Perspectives

Chookaew, S, Oraphan Chanin, Jirapa Charatarawat, Pingpis Sriprasert, and Sudarat Nimpaya. (2015). In creasing Halal Tourism Potential with a t Andaman Gulf in Thailand for Muslim Country. Journal of Eco nomics, Business and Management, 739 -741.

Fahima, Syeda Tamanna \& Evana Nusrat Dooty. (2014). Islamic Tourism: In the Perspective of Bangladesh. Journal of Global Journal of Management and Business Research: F Real Estate Event \& Tourism Management

Gilang Widagdyo, Kurniawan. (2015). Analysis Tourism Market Halal Indonesia. Sahid University Jakarta

Hashim NH, Murphy J, Hashim, NM. 2007. Islam and online imagery on Malaysian tourist destination of Computer-Mediated websites.Journal Communi-cation, 12, 1082-1102.

Jaelani, Aan. (2017). Halal tourism industry in Indonesia: Potential and prospects. Faculty of Shari'ah and Islamic

Kamarudin, LM (2013). Islamic Tourism: The Impacts to Malaysia's Tourism Industry.

Sugiyono. (2012). Quantitative Research Methods, Qualitative, and RD. Bandung: Alfabeta. 